\title{
Isolation and characterization of the gene encoding single-stranded-DNA-binding protein (SSB) from four marine Shewanella strains that differ in their temperature and pressure optima for growth
}

\author{
Lakshmi N. Chilukuri and Douglas H. Bartlett
}

Author for correspondence: Douglas H. Bartlett. Tel: +1619534 5233. Fax: +16195347313. e-mail:dbartlett@ucsd.edu

Center for Marine

Biotechnology and

Biomedicine, Marine Biology

Research Division, Scripps

Institution of Oceanography,

University of California,

San Diego, La Jolla,

CA 92093-0202, USA
The ssb gene, coding for single-stranded-DNA-binding protein (SSB), was cloned from four marine Shewanella strains that differed in their temperature and pressure optima and ranges of growth. All four Shewanella ssb genes complemented Escherichia coli ssb point and deletion mutants, with efficiencies that varied with temperature and ssb gene source. The Shewanella SSBs are the largest bacterial SSBs identified to date (24.9-26.3 kDa) and may be divided into conserved amino- and carboxy-terminal regions and a highly variable central region. Greater amino acid sequence homology was observed between the Shewanella SSBs as a group (72-87\%) than with other bacterial SSBs (52-69\%). Analysis of the amino acid composition of the Shewanella SSBs revealed several features that could correlate with pressure or temperature adaptation. SSBs from the three low-temperature-adapted Shewanella strains were an order of magnitude more hydrophilic than that from the mesophilic strain, and differences in the distribution of eight amino acids were identified which could contribute to either the temperature or pressure adaptation of the proteins. The SSBs from all four Shewanella strains were overproduced and partially purified based upon their ability to bind single-stranded DNA. The differences found among the Shewanella SSBs suggest that these proteins will provide a useful system for exploring the adaptation of protein-protein and protein-DNA interactions at low temperature and high pressure.

Keywords: marine shewanellas, single-stranded-DNA-binding protein (SSB), temperature adaptation, pressure adaptation

\section{INTRODUCTION}

Life in most deep-sea environments is characterized by a temperature of approximately $2{ }^{\circ} \mathrm{C}$, and by hydrostatic pressures extending up to $1100 \mathrm{~atm}(1 \mathrm{~atm}=101 \mathrm{kPa}=$ 1.01 bar). These selective constraints have exerted strong effects on protein evolution. Numerous examples exist of proteins from deep-sea fishes and invertebrates which possess enzymes and structural proteins whose activities and stabilities are optimized for lowtemperature and high-pressure conditions (Somero,

Abbreviation: SSB, single-stranded-DNA-binding protein.

The GenBank accession numbers for the sequence data reported in this paper are U64095, U64096, U64097 and U64098. 1992a, b). A number of enzymes from low-temperatureadapted (psychrophilic) micro-organisms have been distinguished from those of their mesophilic or thermophilic counterparts by an increase in activity accompanied by a decrease in stability when such measurements are compared at a common temperature (RentierDelrue et al., 1993; Hoffman \& Jendrisak, 1990). It therefore seems reasonable to expect that proteins from deep-sea psychrophilic, barophilic ('pressure loving', also referred to as piezophilic; Yayanos, 1995) bacteria will possess proteins modified for function and turnover at extremes of low temperature and high pressure.

Studies with proteins from mesophiles indicate that proteins which form tetramers or aggregates of higher order may be particularly affected by low temperature 
or high pressure. Under both conditions it is believed that subunit dissociation is followed by conformational changes which lead to loss of activity (Weber, 1992; Silva $\&$ Weber, 1993). At low temperatures, the conformationally drifted subunits or aggregates may predominate because of the high activation energy required for conversion back to the native state. At high pressures, it follows from Le Chatelier's principle that a decrease in subunit affinity will result if the volume change for dissociation is negative. The decreased volumes associated with many dissociated protein subunits arise from void volumes associated with subunit-subunit contacts and solvent-protein interactions.

In addition, protein-DNA association may also be sensitive to low temperature or high pressure. Lowtemperature stress leads to the induction of a number of DNA-binding proteins in Escherichia coli, including DNA gyrase A subunit, H-NS, RecA, and CS7.4 (CspA) (Jones et al., 1992). Elevated levels of certain DNAbinding proteins may be necessary at low temperature to compensate for decreased DNA binding, and the resulting effects on DNA structure and function. Although $E$. coli is not known to adapt to changes in hydrostatic pressure, high-pressure treatment of E. coli leads to the induction of some cold-shock proteins, including RecA and H-NS (Welch et al., 1993). This suggests that bacterial cells may perceive a common signal under both low-temperature and high-pressure stresses. In vitro studies also indicate that both low temperature and high pressure can perturb protein-DNA association (Foguel \& Silva, 1994; Macgregor, 1992; Royer et al., 1990).

In order to begin to characterize the biochemical adaptation of protein-protein and protein-DNA interactions to low-temperature and high-pressure environments, we have elected to examine the deduced amino acid sequence of the single-stranded-DNA-binding protein (SSB) from closely related bacteria of the genus Shewanella. Shallow-water and deep-sea Shewanella isolates are available (DeLong \& Yayanos, 1986; Jannasch \& Wirsen, 1984; Jensen et al., 1980; Yayanos et al., 1982) which differ with regard to their temperature and pressure optima and ranges for growth (Table 2). SSB offers several advantages for such comparative analyses, including the fact that it is a small, conserved, homotetrameric DNA-binding protein which performs essential roles in DNA replication, recombination and repair, and for which fluorescence spectroscopic methods have been developed for examining its quaternary structure and DNA-binding characteristics (reviewed by Meyer \& Laine, 1990). Here we present the cloning and sequencing of the $s s b$ genes from four Shewanella strains, and the overproduction and partial purification of the SSB proteins.

\section{METHODS}

Strains and media. Strains and plasmids used in this study are listed in Table 1. More details of the Shewanella strains are given in Table 2 . All E. coli strains were cultured at $37^{\circ} \mathrm{C}$ with the exception of strain PAM5779, which was cultured at $30^{\circ} \mathrm{C}$. E. coli strains were grown in L broth (Davis et al., 1980) and plated on $\mathrm{L}$ agar ( $\mathrm{L}$ broth containing $1.5 \%$ agar, Difco). Medium containing ampicillin $\left(100 \mu \mathrm{g} \mathrm{ml}^{-1}\right)$, chloramphenicol $\left(20 \mu \mathrm{g} \mathrm{ml}^{-1}\right)$ or mitomycin $\mathrm{C}\left(2 \cdot 0 \mu \mathrm{g} \mathrm{ml}^{-1}\right)$ was used for the selection of resistant clones. Shewanella strains SC2A, F1A and $S$. hanedai were routinely cultured in 2216 Marine Medium (28 $\mathrm{g} \mathrm{l}^{-1}$, Difco), at their temperature optima (Table 2) and at $1 \mathrm{~atm}$ hydrostatic pressure. Shewanella strain PT99 was cultured at $9^{\circ} \mathrm{C}$ and $680 \mathrm{~atm}$ hydrostatic pressure in

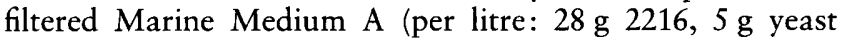
extract, $10 \mathrm{~g}$ Casamino acids, $0.22 \mathrm{~g}$ trimethylamine- $N$-oxide dihydrate, $2 \mathrm{~g}$ sodium succinate, $2.38 \mathrm{~g}$ HEPES). Growth temperature optimum for $S$. hanedai was determined for cultures grown aerobically in 2216 Marine Medium at $1 \mathrm{~atm}$; the growth pressure optimum was determined for cultures grown microaerobically in Marine Medium A.

Shewanella SC2A cosmid library preparation. The SC2A genomic library was prepared in the cosmid vector Supercos I as directed in the kit manual (Stratagene), using SC2A genomic DNA partially digested with Sau $3 \mathrm{~A}$ (30 kb average DNA fragment size; Sambrook et al., 1989). The cosmid library was screened for the SC2A $s s b$ gene by the method of de Vries \& Wackernagel (1994), by complementation of the E. coli ssb point mutant PAM5779 (ssb-113).

DNA manipulations and hybridization. Chromosomal DNA was isolated by the method of Silhavy et al. (1984). DNA fragments containing the entire $s s b$ gene from each of the Shewanella strains were identified by Southern blot analysis (Southern, 1975) using either the first 504 bp of the Shewanella SC2A $s s b$ gene (see below) or the E. coli ssb gene (the $0.7 \mathrm{~kb}$ Bam HI-EcoRI fragment of pJA40: Table 1) as a probe. All probes were labelled with $\left[\alpha_{-}{ }^{32} \mathrm{P}\right] \mathrm{dATP}$ by random priming (Boehringer-Mannheim). Size fractionation of DNA, ligation into M13mp18, screening of the M13 library and subcloning into the plasmid vector pUC8 or pUC19, were performed as described by Sambrook et al. (1989). Plasmid ligations were introduced into either E. coli DH5 $\alpha$ or E. coli XL-1 Blue, by transformation of competent cells. Plasmids were prepared either by the alkaline lysis method (Sambrook et al., 1989) or using QIAprep columns (QIAGEN). Gel-purified DNA fragments were obtained using the QIAquick gel purification kit (QIAGEN).

DNA sequencing and analysis. Double-stranded and singlestranded DNA sequencing was performed by the Taq DyeDeoxy thermal-cycle sequencing method (Applied Biosystems). Plasmids pLC10, pLC20, pLC30 and pLC40 were the source of the Shewanella SC2A, S. hanedai, Shewanella F1A, and Shewanella PT99 ssb genes, respectively. Additional information on the PT99 $s s b$ sequence and proximal ORFs was obtained from an M13mp18 DNA clone. Primers used for sequencing included the M13 universal forward and reverse primers and several custom-synthesized primers specific to each Shewanella ssb sequence. Completed sequencing reactions were purified through Centri-Sep columns (Princeton Separations) and analysed on an Applied Biosystems model $373 \mathrm{~A}$ automated sequencer.

Homology searches were conducted using the BLAST Network Service at the National Center for Biotechnology Information, National Institutes of Health (Altschul et al., 1990). Multiple SSB sequence alignment was performed using the NEWAT 87 programs SCORE and PREALIGN (Feng \& Doolittle, 1990). The percentage identity/similarity values of the nucleotide and deduced protein sequences were calculated using the University of Wisconsin Genetics Computer Group (GCG) 
Table 1. Strains and plasmids used in this study

\begin{tabular}{|c|c|c|}
\hline & Relevant genotype & Source or reference \\
\hline \multicolumn{3}{|l|}{ E. coli } \\
\hline $\mathrm{DH} 5 \alpha$ & $\mathrm{F}^{-} \phi 80 \mathrm{~d}$ lacZ $\Delta(\operatorname{lac} Z Y A-\arg F) U 169 \operatorname{rec} A 1$ end $A 1$ & Hanahan (1983) \\
\hline $\mathrm{F}^{\prime} \mathrm{DH} 5 \alpha$ & $\mathrm{F}^{\prime}$ derivative of $\mathrm{DH} 5 \alpha$ & Hanahan (1983) \\
\hline XL1 Blue & recA1 lac $\left\{\mathrm{F}^{\prime}\right.$ pro $A B$ lacI $\left.^{\mathrm{q}} \Delta \mathrm{M} 15, \mathrm{Tn} 10\right\}$ & Stratagene \\
\hline PAM5779 & $s s b-113$ & Johnson (1977) \\
\hline RDP268 & $\Delta(s s b-u v r A)$ & Porter et al. (1990) \\
\hline \multicolumn{3}{|l|}{ Shewanella } \\
\hline SC2A & $s s b^{+}$ & Yayanos et al. (1982) \\
\hline S. hanedai & $s s b^{+}$ & Jensen et al. (1980) \\
\hline F1A & $s s b^{+}$ & Jannasch \& Wirsen (1984) \\
\hline PT99 & $s s b^{+}$ & DeLong \& Yayanos (1986) \\
\hline \multicolumn{3}{|l|}{ Plasmids } \\
\hline pJA40 & E. coli $s s b^{+}$gene in pUC9 & Brandsma et al. (1985) \\
\hline pSBH5 & E. coli $s s b^{+}$gene in pBluescript II KS & de Vries \& Wackernagel (1994) \\
\hline pACYCssb & E. coli $s s b^{+}$gene in pACYC184, $\mathrm{Cm}^{\mathrm{r}}$ & Porter et al. (1990) \\
\hline pUC8 & High copy number vector, $A p^{r}$ & Norrander et al. (1983) \\
\hline pUC19 & High copy number vector, $A p^{r}$ & Norrander et al. (1983) \\
\hline pET23a & High copy number expression vectror, $A p^{r}$ & Novagen \\
\hline pLC10 & $S . \mathrm{SC} 2 \mathrm{~A} s s b^{+}$gene in pUC8 & This work \\
\hline pLC20 & S. hanedai $s s b^{+}$gene in pUC19 & This work \\
\hline pLC30 & $S$. F1A $s s b^{+}$gene in pUC19 & This work \\
\hline pLC40 & S. PT99 $s s b^{+}$gene in pUC19 & This work \\
\hline pLC101 & S. SC2A $s s b^{+}$gene in pET23a & This work \\
\hline pLC201 & S. hanedai $s s b^{+}$gene in pET23a & This work \\
\hline pLC301 & $S . \mathrm{F} 1 \mathrm{~A} s s b^{+}$gene in pET23a & This work \\
\hline pLC401 & $S$. PT99 $s s b^{+}$gene in pET23a & This work \\
\hline \multicolumn{3}{|l|}{ Cosmids } \\
\hline SuperCos I & Broad host range cosmid vector & Stratagene \\
\hline \multicolumn{3}{|l|}{ Phage } \\
\hline M13mp18 & Phage cloning vector & Norrander et al. (1983) \\
\hline mGP1-2 & $\begin{array}{l}\text { M13 derivative containing phage T7 RNA polymerase } \\
\text { on a BamHI-SalI fragment derived from the plasmid } \\
\text { pGP1-1 }\end{array}$ & $\begin{array}{l}\text { Hostomski et al. (1989), Tabor \& Richardson } \\
\text { (1985), S. Tabor \& C. C. Richardson, } \\
\text { unpublished }\end{array}$ \\
\hline
\end{tabular}

Table 2. Description of Shewanella strains used in this study

\begin{tabular}{|lcrrl|}
\hline Strain & $\begin{array}{c}\boldsymbol{T}_{\text {opt }} * \\
\left({ }^{\circ} \mathrm{C}\right)\end{array}$ & $\begin{array}{r}\text { Isolation } \\
\text { depth } \\
(\mathbf{m})\end{array}$ & $\begin{array}{r}\boldsymbol{P}_{\text {opt }} \dagger \\
(\mathbf{a t m})\end{array}$ & Reference for $\boldsymbol{T}_{\text {opt }}$ and $\boldsymbol{P}_{\text {opt }}$ \\
\hline SC2A & 20 & 2000 & 136 & Tobal (1993) \\
S. hanedai & $12-18$ & 0 & 1 & This study \\
F1A & 8 & 4900 & 300 & Jannasch \& Wirsen (1984) \\
PT99 & $9 \neq$ & 8600 & $680 \neq$ & \\
\hline
\end{tabular}

*Optimum growth temperature.

†Pressure for optimum growth at optimum temperature.

$\ddagger P_{\text {opt }}$ and $T_{\text {opt }}$ not determined; values indicate culture parameters.

program BESTFIT (Smith, 1988; Devereux et al., 1984). The distribution of the amino acids in the entire SSB protein and the indicated portions was determined using the STADEN program ANALYSEP (Staden, 1988) and the deduced hydrophilicity of the proteins was determined by the method of Hopp \& Woods (1981). 
Amplification by polymerse chain reaction and cloning of the ssb genes. All PCR reactions were performed using $P f u$ polymerase (Stratagene) at annealing temperatures ranging from $50^{\circ} \mathrm{C}$ to $55^{\circ} \mathrm{C}$, in $100 \mu \mathrm{l}$ buffer containing $20 \mathrm{mM}$ Tris $/ \mathrm{HCl}(\mathrm{pH} 8.75), 10 \mathrm{mM} \mathrm{KCl}, 10 \mathrm{mM}\left(\mathrm{NH}_{4}\right)_{2} \mathrm{SO}_{4}, 2 \mathrm{mM}$ $\mathrm{MgSO}_{4}, 0.1 \%$ Triton $\mathrm{X}-100,100 \mu \mathrm{g}$ bovine serum albumin $\mathrm{ml}^{-1}, 250 \mu \mathrm{M}$ of each dNTP, $1 \mu \mathrm{M}$ each primer and about $250 \mathrm{ng}$ genomic DNA (Saiki et al., 1988). The following primers were employed for the amplification of the Shewanella ssb genes: Shewanella SC2A, 5' ATT CAT ATG GCT AGT CGT GGT GTG 3' (forward), 5' GCG AGC AAG CTT GAA ATA CGG CTG GCA $3^{\prime}$ (reverse); $S$. hanedai, $5^{\prime}$ AAT CAT ATG GCC AGT CGT GGT GTC 3' (forward), 5' GCT AAG CTT GCG TAG ATA TTG CTC CCT AGA ACG 3' (reverse); Shewanella F1A, 5' GCG AGC AAG CTT CTA GAA CGG GAT 3' (reverse); Shewanella PT99, 5' GCG ACG AAG CTT GCC GTA GCG AGG TTT GAG 3' (reverse). The Shewanella SC2A forward primer was used for amplifying the F1A and PT99 ssb genes. Each forward primer incorporated the NdeI restriction site (underlined), while the reverse primers incorporated a HindIII site (underlined) for ease of cloning into the expression vector pET23a (Novagen). Products of PCR reactions were purified using the QIAquick PCR purification kit, restricted with NdeI and HindIII, and ligated into correspondingly restricted pET23a. The ligations were introduced into $E$. coli $\mathrm{F}^{\prime} \mathrm{DH} 5 \alpha$ by transformation of competent cells. The presence of insert was verified by restriction analyses, yielding plasmids pLC101 (Shewanella SC2A), pLC201 (S. hanedai), pLC301 (Shewanella F1A) and pLC401 (Shewanella PT99). The following primers were designed to amplify the first 504 bp of the SC2A $s s b$ gene to use as a probe for $s s b$ genes from the other Shewanella strains: $5^{\prime}$ ATG GCT AGT CGT GGT GTG AA 3' (forward), 5' TTA CCC TGC TGC GGC AGG CGC AGT 3' (reverse). All PCR amplifications were performed using genomic DNA.

Complementation of E. coli PAM5779 (ssb-113) temperature sensitivity. E. coli PAM5779 was transformed with plasmids pLC10, pLC20, pLC30 and pLC40 and equal aliquots of the transformation were plated on $\mathrm{L}$ agar plates with ampicillin alone or with ampicillin and mitomycin C. Ampicillincontaining plates were incubated at $30^{\circ} \mathrm{C}$, and those containing both ampicillin and mitomycin $\mathrm{C}$ at $37^{\circ} \mathrm{C}$. Counts of $A p^{r}$ Mit $C^{r}$ colonies were normalized to counts of $A p^{r}$ colonies and expressed as a percentage. Colony counts on the ampicillin plates, for each transformation, were designated the $100 \%$ value. Transformations were performed in triplicate and the standard deviation of the normalized values was calculated.

Complementation of E. coli PAM5779 UV sensitivity. Aliquots $(5 \mu \mathrm{l})$ of exponential-phase cultures $\left(\mathrm{OD}_{590} 0 \cdot 8\right)$ of E. coli PAM5779 transformed with pLC10, pLC20, pLC30 or pLC40 were gridded onto L agar plates. The gridded cultures were irradiated using a germicidal lamp (200-280 nm, Ultraviolet Products). UV emission was measured at $1.41 \mathrm{~J} \mathrm{~m}^{-2} \mathrm{~s}^{-1}$ (calibrated with an International Light IL-1500 research radiometer) with exposure to UV ranging from 0 to $127 \mathrm{~J} \mathrm{~m}^{-2}$ along the grid. After irradiation, plates were covered and incubated at either $30^{\circ} \mathrm{C}$ or $37^{\circ} \mathrm{C}$. Triplicate samples were irradiated and incubated at each temperature.

Complementation of the $\boldsymbol{E}$. coli ssb deletion mutant RDP268. E. coli RDP268(pACYCssb) (Porter \& Black, 1991) was transformed with the Shewanella ssb plasmids pLC10, pLC20, pLC30 and pLC40. A single $\mathrm{Ap}^{\mathrm{r}} \mathrm{Cm}^{\mathrm{r}}$ colony from each transformation was grown at $37^{\circ} \mathrm{C}$ or $22^{\circ} \mathrm{C}$ in $\mathrm{L}$ broth containing ampicillin and subcultured daily for $9 \mathrm{~d}$. Aliquots were removed at $2 \mathrm{~d}$ intervals and dilutions replica-plated on $\mathrm{L}$ agar plates containing ampicillin. The relative proportion of
$\mathrm{Ap}^{\mathrm{r}} \mathrm{Cm}^{\mathrm{s}}$ colonies was determined by replica gridding of $\mathrm{Ap}^{\mathrm{r}}$ colonies on plates containing ampicillin, and ampicillin plus chloramphenicol.

Overproduction and partial purification of the Shewanella SSBs. Aliquots $(100 \mu \mathrm{l})$ of overnight cultures of E. coli $\mathrm{F}^{\prime} \mathrm{DH} 5 \alpha$ containing pLC101, pLC201, pLC301 or pLC401 were diluted into $6 \mathrm{ml} \mathrm{L}$ broth containing ampicillin and aerated at $37^{\circ} \mathrm{C}$ until an $\mathrm{OD}_{590}$ of 0.8 was obtained. Overproduction of the SSB protein was induced by delivery of T7 RNA polymerase through infection with the induction phage mGP1-2 at a multiplicity of infection of 10-100 (Hostomski et al., 1989) and addition of IPTG (Sigma) to a final concentration of $0.2 \mathrm{mM}$. Aeration was continued for $90 \mathrm{~min}$ and the cells harvested by centrifugation at $14000 \mathrm{~g}$ for $3 \mathrm{~min}$. SSB was partially purified from the induced cells by the method of de Vries \& Wackernagel (1994) with the following modifications: affinity chromatography using ssDNA cellulose (Sigma $; 1.5 \mathrm{ml}$ ssDNA cellulose per ml lysate) was done by batch elution rather than on a column, with a $0.3 \mathrm{M} \mathrm{KCl}$ wash in buffer $\mathrm{A}$ (50 mM Tris/ $\mathrm{HCl}, \mathrm{pH} 7 \cdot 5,1 \mathrm{mM}$ EDTA, $10 \mathrm{mM} \beta$-mercaptoethanol, and $25 \%, \mathrm{v} / \mathrm{v}$, glycerol) and elution with $2.0 \mathrm{M} \mathrm{KCl}$ in buffer $\mathrm{A}$. The extent of protein overproduction and enrichment was visualized by electrophoresis of samples through a $15 \%$ SDS polyacrylamide gel (Laemmli, 1970).

\section{RESULTS}

\section{Cloning of the ssb gene from the marine Shewanella strains}

The temperature- and UV-sensitive E. coli ssb mutant PAM5779 (ssb-113; Table 1) was transformed with a Shewanella SC2A genomic library prepared in the cosmid vector Supercos 1 (Stratagene). Among roughly 140000 transformants screened, 22 clones resistant to both ampicillin and mitomycin $\mathrm{C}$ were identified, all of which contained cosmids with an insert size of about $30 \mathrm{~kb}$. Southern hybridization of three of the 22 clones with a probe consisting of the $E$. coli ssb gene identified a single strongly hybridizing band corresponding to a $1.6 \mathrm{~kb}$ EcoRI fragment. This fragment was subcloned onto the high-copy-number plasmid pUC8 (Norrander et al., 1983), resulting in plasmid pLC10.

Chromosomal DNA fragments containing the entire $s s b$ gene from each of the four Shewanella strains were identified by restriction enzyme analysis and Southern hybridization with the Shewanella SC2A ssb probe. This probe was generated by PCR amplification of the first $504 \mathrm{bp}$ of the SC2A $s s b$ gene, following nucleotide sequence determination (see below). After size fractionation of the restricted DNA, phage M13mp18 DNA libraries were constructed for S. hanedai, Shewanella F1A and Shewanella PT99, as described in Methods. The resulting plaques were screened for the $s s b$ gene using the SC2A $s s b$ probe. Strongly hybridizing plaques were plaque purified and insert sequences present in the phage vector were subcloned onto the plasmid vector pUC8 (S. hanedai ssb) or pUC19 (F1A ssb and PT99 $s s b$ ). This resulted in plasmids pLC20, pLC30 and pLC40, containing a $1.7 \mathrm{~kb}$ XboI-Sal $S$. hanedai DNA fragment, a $2.7 \mathrm{~kb}$ XbaI-HindIII Shewanella F1A DNA fragment, and a $3.7 \mathrm{~kb}$ EcoRI-HindIII Shewanella PT99 DNA fragment, respectively. 


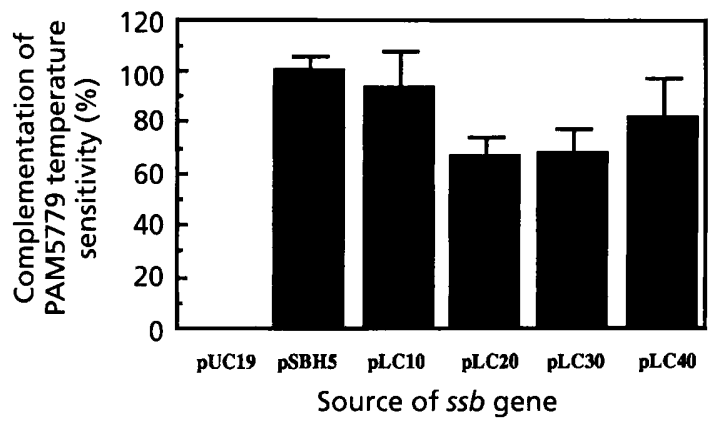

Fig. 1. Complementation of the temperature sensitivity of the E. coli ssb-113 mutant PAM5779 by Shewanella ssb genes. Strain PAM5779 was transformed with plasmids pUC19 (vector control), pSBH5 (E. coli ssb), pLC10 (Shewanella SC2A ssb), pLC20 (S. hanedai ssb), pLC30 (Shewanella F1A ssb) and pLC40 (Shewanella. PT99 ssb). The level of complementation of the mutant was determined as described in Methods.

\section{Complementation of an $E$. coli ssb point mutant}

The E. coli ssb point mutant PAM5779 (ssb-113) is sensitive to DNA-damaging agents such as UV irradiation and mitomycin $\mathrm{C}$ (Johnson, 1977). In the presence of mitomycin C, PAM5779 grows very poorly or not at all at $37^{\circ} \mathrm{C}$ but is capable of normal growth at $30{ }^{\circ} \mathrm{C}$. Transformation of the mutant with either pSBH5 (E. coli ssb; Table 1), or the Shewanella ssb-containing plasmids pLC10, pLC20, pLC30 or pLC40, restored growth ability at $37^{\circ} \mathrm{C}$ in the presence of mitomycin C. The extent to which these plasmids complemented the temperature sensitivity of the mutant $E$. coli strain is shown in Fig. 1. ssb from the mesophilic Shewanella strain SC2A showed levels of complementation of the mutation comparable to that produced by the wild-type E. coli $s s b$ gene. Complementation by $s s b$ from the psychrotrophic S. hanedai and psychrophilic Shewanella strains F1A and PT99 was less efficient. Transformation of PAM5779 with the control plasmid, pUC19 alone, did not restore the ability to grow at $37^{\circ} \mathrm{C}$.

Resistance to UV irradiation was also evaluated for PAM5779 (ssb-113) in the presence or absence of highcopy-number plasmids bearing either the wild-type $E$. coli $s s b$ or the marine Shewanella ssb genes. The effect of increasing UV irradiation on the E. coli ssb-113 mutant when transformed with the plasmids pUC19, pSBH5, pLC10, pLC20, pLC30 and pLC40 is shown in Fig. 2. Under the conditions employed, the highly UV-sensitive $\operatorname{rec} A$ E. coli strain DH5 $\alpha$ did not survive even $13 \mathrm{~J} \mathrm{~m}^{-2}$ exposure, while the limit of UV exposure for PAM5779 survival was $51 \mathrm{~J} \mathrm{~m}^{-2}$. As expected, the control plasmid pUC19 did not confer any UV resistance upon PAM5779. With the exception of pLC40, carrying the Shewanella PT99 $s s b$, all the $s s b$-containing plasmids increased the UV resistance of PAM5779. Wild-type E. coli $s s b$ and $s s b$ from the mesophilic Shewanella, SC2A, conferred UV resistance for an irradiation of up to $127 \mathrm{~J} \mathrm{~m}^{-2}$. The $s s b$ genes from the $S$. hanedai and Shewanella F1A did not complement the mutation as

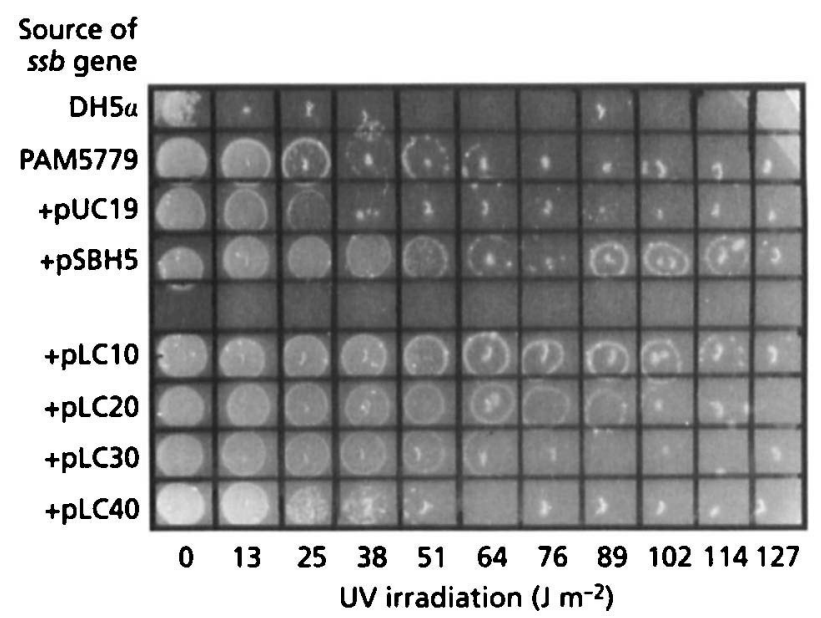

Fig. 2. Complementation of the UV sensitivity of $E$. coli PAM5779 (ssb-113) by Shewanella ssb genes. Aliquots $(5 \mu \mathrm{l})$ of exponential-phase cultures $\left(\mathrm{OD}_{590} 0 \cdot 8\right)$ of $E$. coli strains $\mathrm{DH} 5 \alpha$ (recA mutant) and PAM5779, as well as strain PAM5779 transformed with the plasmids pUC19, pSBH5, pLC10, pLC20, $\mathrm{pLC} 30$ and pLC40 (indicated on the left of the figure) were gridded on $\mathrm{L}$ agar plates. The gridded cultures were incrementally exposed to UV irradiation from 0 to $127 \mathrm{~J} \mathrm{~m}^{-2}$. The extent of subsequent growth at $37^{\circ} \mathrm{C}$ after $18 \mathrm{~h}$ indicated the UV resistance of each strain.

efficiently, survival being restricted to irradiation of less than $102 \mathrm{~J} \mathrm{~m}^{-2}$ and $76 \mathrm{~J} \mathrm{~m}^{-2}$, respectively. The $\mathrm{UV}$ resistance of the $s s b-113$ mutant strain bearing the Shewanella PT99 ssb plasmid, pLC40, was not significantly higher than that of the mutant alone. However, unlike the results obtained at either $30^{\circ} \mathrm{C}$ or $37^{\circ} \mathrm{C}$, complementation of UV sensitivity by Shewanella PT99 $s s b$ was evident at $22^{\circ} \mathrm{C}$ (data not shown).

\section{Complementation of an $E$. coli ssb deletion mutant}

SSB is an essential protein and $E$. coli ssb deletion mutants have been shown to be non-viable (Porter \& Black, 1991). The E. coli ssb deletion mutant RDP268 (Table 1) carries a helper plasmid pACYCssb which provides the essential ssb gene along with a chloramphenicol-resistance marker. Plasmid bumping experiments were carried out to replace the E. coli ssbbearing plasmid in the deletion mutant with the Shewanella ssb-bearing plasmids pLC10, pLC20, pLC30 and pLC40, as outlined in Methods. It has been previously demonstrated that the $s s b$ genes from the enteric bacteria Serratia marcescens and Proteus mirabilis can complement the E. coli deletion mutant and replace pACYCssb (de Vries \& Wackernagel, 1994; de Vries et al., 1994). RDP268 transformants containing both the E. coli ssb plasmid $\left(\mathrm{Cm}^{\mathrm{r}}\right)$ and the Shewanella $s s b$ plasmids $\left(\mathrm{Ap}^{\mathrm{r}}\right)$ were grown at $22^{\circ} \mathrm{C}$ or $37^{\circ} \mathrm{C}$ and selection was maintained only for the ampicillin-resistance marker on the Shewanella ssb plasmids. Loss of the original pACYCssb plasmid resulted in a $\mathrm{Ap}^{\mathrm{r}} \mathrm{Cm}^{\mathrm{s}}$ strain. The Shewanella ssb plasmids pLC10, pLC20 and 


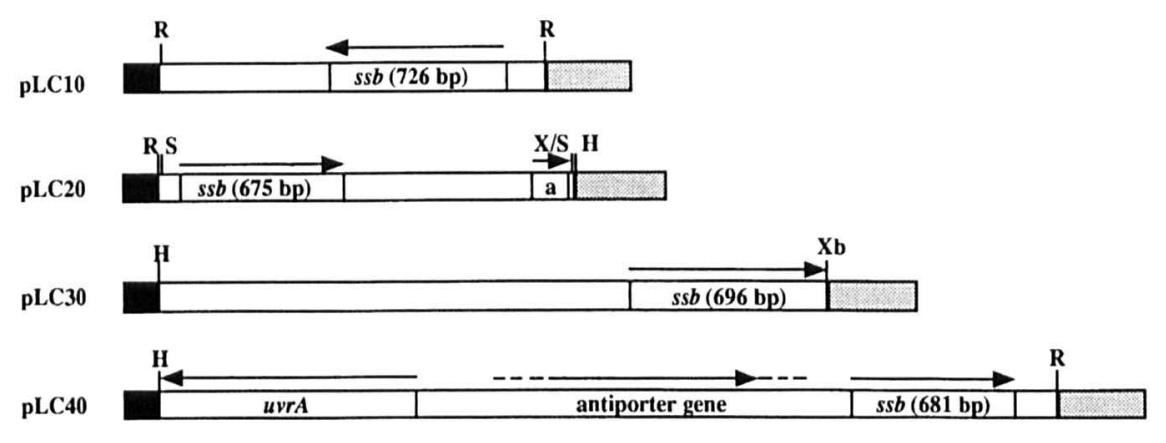

$0.6 \mathrm{~kb}$
Fig. 3. Schematic view of the size, position and orientation of the cloned Shewanella ssb genes and additional proximal ORFs present in plasmids pLC10, pLC20, pLC30 and pLC40. Solid box, lac promoter; stippled box, lac $Z$ gene; boxes with overlying arrows, identified ORFs; arrows, ORF polarity; $H$, HindIII site; R, EcoRI site; S, Sall site; $X$, Xhol site; Xb, Xbal site; a, portion of an ORF with homology to the csgF gene of $E$. coli.
pLC30 replaced the E. colissb plasmid at both $22{ }^{\circ} \mathrm{C}$ and $37^{\circ} \mathrm{C}$. Within the duration of the experiment, the Shewanella PT99 ssb plasmid pLC40 replaced pACYCssb at $22^{\circ} \mathrm{C}$ but not at $37^{\circ} \mathrm{C}$.

\section{Sequence analyses of the four Shewanella ssb genes}

The nucleotide sequences of the $s s b$ genes on plasmids pLC10, pLC20, pLC30 and pLC40 were determined using a combination of vector-specific and $s s b$ internal sequencing primers. Fig. 3 presents the size, position and orientation of the four $s s b$ genes. In addition to the $s s b$ genes, a number of additional ORFs with similarity to other gene products of known function were identified using the BLAST network service (Altschul et al., 1990) to search the National Center for Biotechnology Information nucleic acid databases. For example, a portion of an ORF with strong homology to the UvrA protein of Haemophilus influenzae $\left(P\right.$ value $\left.2.5 \times 10^{-66}\right)$, E. coli $(P$ value $\left.2.7 \times 10^{-63}\right)$ and Salmonella typhimurium $(P$ value $\left.2 \cdot 8 \times 10^{-63}\right)$, among others, was found about $1800 \mathrm{bp}$ upstream on the Shewanella PT99 ssb gene. Between this ORF and the $s s b$ gene is a third ORF oriented in the direction of the $s s b$ gene and having strong homology to a variety of antiporter proteins isolated from E. coli, Staphylococcus aureus and Bacillus subtilis, among others. This arrangement of the ssb and uvrA gene differs from that seen in the enteric bacterial $s s b$ genes examined to date (de Vries \& Wackernagel, 1994; de Vries et al., 1994; Jarosik \& Hansen, 1994). Although the $s s b$ and $u v r A$ genes are divergently transcribed in Shewanella PT99, as is the case with many enteric bacteria, the PT99 genes are interrupted by a third gene whose product has no obvious significance to DNA repair. In enteric bacteria, $u v r A$ and $s s b$ gene expression is regulated by the DNA-damage-inducible LexA protein (Walker, 1984). No sequences similar to the canonical LexA-binding sequence of E. coli (Walker, 1984; also referred to as the SOS box) are evident in the apparent intergenic region between the UvrA-like and antiporterlike ORFs. However, a sequence with similarity to the consensus sequence of the E. coli SOS box is located 82-98 bp upstream of the Shewanella PT99 ssb gene.
Approximately 860 bp upstream of the $S$. hanedai ssb is part of an ORF with significant homology ( $P$ value $0 \cdot 036)$ to the $c s g F$ gene of $E$. coli $\mathrm{K}-12$. The $\operatorname{csg} F$ gene is believed to be necessary for the transport and assembly of curli polymers, thin coiled surface structures that mediate binding to extracellular matrix and serum proteins by E. coli K-12 (Hammar et al., 1995).

The Shewanella ssb genes were $75-93 \%$ identical to one another, while the homologies to other bacterial $s s b$ genes ranged from 63 to $70 \%$. At the protein level, the extent of homology shared between the deduced Shewanella SSB amino acid sequences ranged from 72 to $87 \%$, whereas the identity shared between any of the Shewanella SSBs and any of the bacterial SSBs ranged from 52 to $69 \%$. The Shewanella SSBs were also distinguished in size from one another and as a group from other bacterial SSBs. They range from 226 aa residues (S. hanedai SSB) to 243 a residues (Shewanella SC2A SSB) and are considerably larger than the E. coli SSB, which has 177 residues. In contrast, all of the remaining bacterial SSBs characterized are of similar size to E. coli SSB. These data suggest that the Shewanella SSBs constitute a distinct subfamily of SSB proteins. Indeed, construction of an SSB protein phylogenetic tree using the maximum parsimony PAUP program (Swofford, 1991) indicated branching at the $100 \%$ confidence level between the Shewanella SSBs and all other bacterial SSBs (data not shown).

Alignment of the deduced amino acid sequence of the Shewanella strains with that of E. coli SSB revealed several interesting features (Fig. 4). All five SSBs show a high degree of similarity up to position 114 of the Shewanella SSBs (position 126 of the E. coli SSB). Within this region, nearly all the residues shown to be involved either in DNA binding (W40, W54, F60, W88) or subunit interaction (H55) in E. coli (reviewed by Meyer \& Laine, 1990) are found in identical positions in the Shewanella SSBs. Of the residues listed above, only F60 is substituted with a tyrosine residue in all four Shewanella SSBs. In this portion of the protein, there are only three unconserved substitutions within the shewanellas, in positions 48, 93 and 106, positions known to be highly 


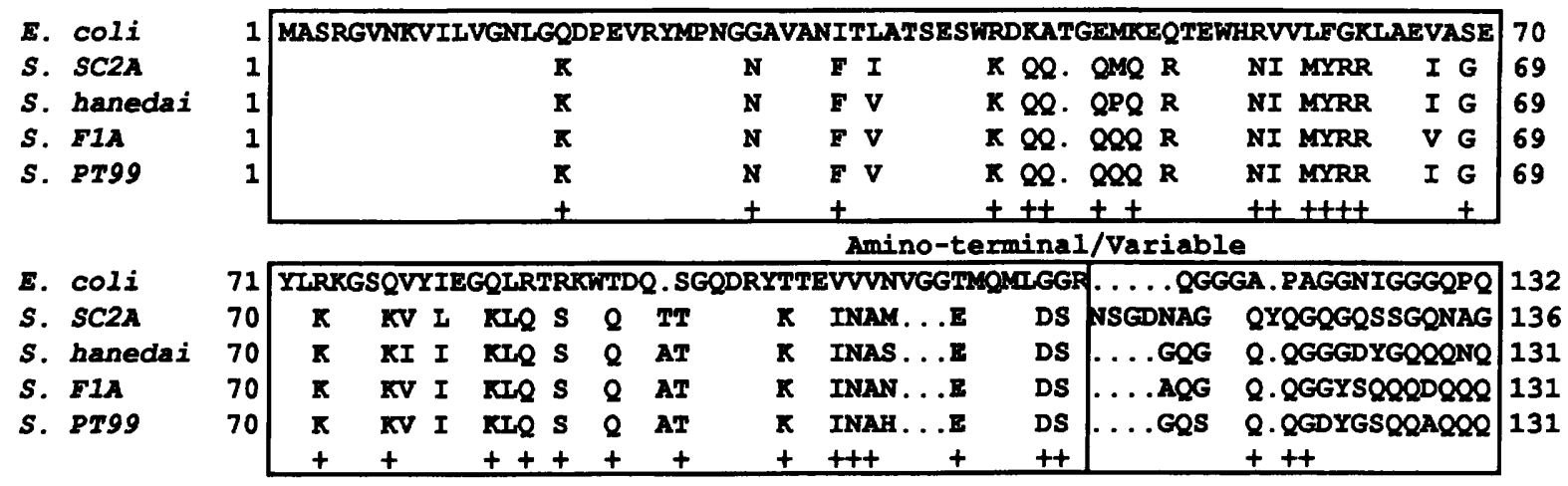

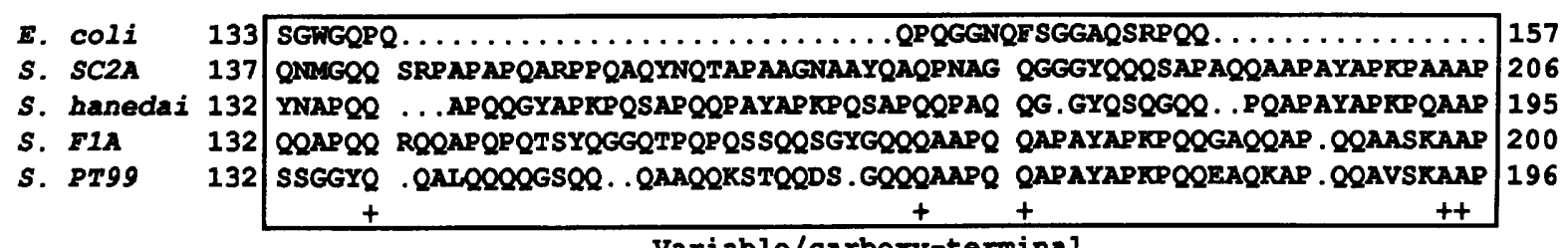

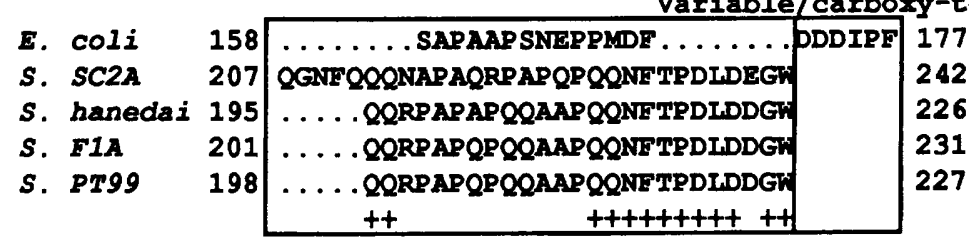

Fig. 4. Alignment of amino acid sequence of SSBs from E. coli and Shewanella SC2A, S. hanedai, Shewanella F1A and Shewanella PT99. Boxed regions indicate the amino-terminal, carboxy-terminal and central variable regions of the protein. Spaces indicate amino acid residues that are identical in all five SSB sequences; plus signs indicate amino acid residues which are identical between the Shewanella SSB sequences alone; dots indicate gaps in the sequence. The first and last amino acid in each line of sequence is numbered.

variable among the other bacterial SSBs. Most of the remainder of the Shewanella SSBs consists of a highly variable central portion, much of which is absent in other bacterial SSBs. A stretch of six identical amino acid residues, PAYAPK, is seen in this region of all four Shewanella SSBs but is absent in other SSBs. S. hanedai has an internal repeat of these residues. Finally, all of the Shewanella SSBs contain a well-conserved carboxyterminal domain of 19 residues, the last six amino acids of which are also shared with other bacterial SSBs. Within these 19 residues, the Shewanella SC2A SSB has a single conserved substitution of a glutamic acid residue for an aspartic acid residue at position 234.

\section{Overproduction and partial purification of the Shewanella SSBs}

The Shewanella ssb genes were cloned into the expression vector $\mathrm{pET} 23 \mathrm{a}$ (Stratagene) to facilitate the controlled overproduction of the cloned $s s b$ gene products. Incorporation of an NdeI site into one of the primers employed for PCR amplification and cloning permitted the optimal placement of the $s s b$ start codons downstream of the ribosome-binding site of the expression vector and under the control of the T7 promoter. Plasmids pLC101, pLC201, pLC301 and
pLC401 were constructed for the purification of SSB from Shewanella SC2A, S. hanedai, Shewanella F1A and Shewanella PT99, respectively. Upon induction, each expression plasmid directed the overproduction of a single polypeptide to approximately $10 \%$ of the total cell protein in $90 \mathrm{~min}$ and $30 \%$ of the total cell protein in $4 \mathrm{~h}$. No proteins were induced in control experiments involving plasmid pET23a alone. For the purpose of partially purifying the recombinant SSBs, the $90 \mathrm{~min}$ induction period was utilized in order to reduce the amount of SSB localizing to inclusion bodies within the cells (our unpublished results). Fig. 5 shows the level of SSB production before and $90 \mathrm{~min}$ after T7 promoter activation. Based on their deduced amino acid sequences the molecular masses of the Shewanella SSBs are $24.9 \mathrm{kDa}$ (S. hanedai), $26.3 \mathrm{kDa}$ (SC2A), $25.6 \mathrm{kDa}(\mathrm{F} 1 \mathrm{~A})$, and $25.2 \mathrm{kDa}$ (PT99). As observed for other bacterial SSBs, all four Shewanella SSBs migrated somewhat more slowly in SDS-PAGE gels than would be expected based on their predicted molecular masses. SSBs from SC2A and $S$. hanedai were found at positions corresponding to a molecular mass of about $33 \mathrm{kDa}$, while the F1A SSB was found at about $35 \mathrm{kDa}$ and the PT99 SSB at about $36 \mathrm{kDa}$.

After induction the Shewanella SSBs in cell lysates were qualitatively assessed for ssDNA-binding ability fol- 


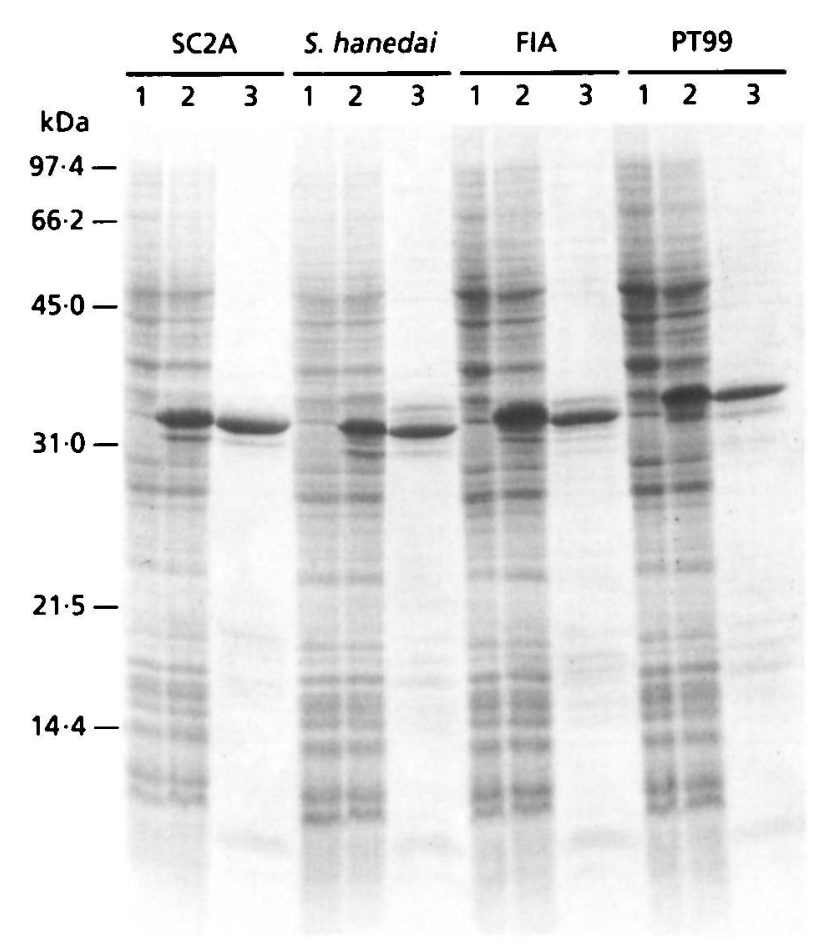

Fig. 5. Overproduction and partial purification of SSB protein from Shewanella SC2A, S. hanedai, Shewanella F1A and Shewanella PT99. Overproduction of Shewanella SSB protein was induced in $E$. coli $\mathrm{F}^{\prime} \mathrm{DH} 5 \alpha$ transformed with pLC101, pLC201, pLC301 and pLC401. The figure shows an SDS-PAGE gel with lysate from each of the transformants, prior to induction (lanes 1) and after a 90 min induction (lanes 2). Lane 3 for each strain shows enrichment for the overproduced protein after equilibration with ssDNA cellulose and elution with $2 \mathrm{M} \mathrm{KCl}$. Positions of molecular mass markers are indicated.

lowing the SSB purification protocol of de Vries \& Wackernagel (1994). Cell lysates were incubated with ssDNA cellulose at $4{ }^{\circ} \mathrm{C}$ followed by removal of unbound and loosely bound proteins from the resins by several buffer washes. Proteins were eluted from stable protein-DNA complexes by washing resins in buffer containing $2 \mathrm{M} \mathrm{KCl}$. As seen in Fig. 5, fractions obtained by a high-salt elution from the ssDNA cellulose were considerably enriched in SSB, verifying that overproduced SSB from each of the four marine Shewanella strains was capable of binding to ssDNA. SSBs from the barophilic shewanellas F1A and PT99 appeared to bind the ssDNA with lower affinity than SSBs from SC2A and $S$. hanedai. This was evident in the high amounts of F1A and PT99 SSB removed in the $0.3 \mathrm{M} \mathrm{KCl}$ wash and in the reduced SSB yield obtained during the $2 \mathrm{M} \mathrm{KCl}$ treatment.

\section{DISCUSSION}

In this study the gene encoding SSB was isolated from four related Shewanella strains which differ with regard to temperature and pressure adaptation. Using several different criteria the $s s b$ genes were shown to comp- lement $E$. coli $s s b$ mutants. In addition, the nucleotide sequences of the $s s b$ genes were obtained, and the $s s b$ genes were overexpressed and SSBs shown to bind ssDNA.

The complementation of the E. coli ssb mutants by the Shewanella ssb genes is remarkable in that each of the SSBs so tested is functioning outside its normal osmolarity, temperature and pressure. Changes in any of these conditions could affect protein quaternary structure as well as ligand interaction (Jaenicke, 1991; Ludlow \& Clark, 1991; Royer, 1995; Robinson \& Sligar, 1995). E. coli SSB protein binds ssDNA as a tetramer rather than by the assembly of the tetramers on DNA after the binding of monomers or dimers (Bujalowski \& Lohman, 1991). Thus, the quaternary structure of these recombinant proteins in vivo is relevant to their ability to complement $E$. coli $s s b$ mutations. From the ability of the overproduced protein to bind ssDNA in vitro (Fig. 5), it may be assumed that at the high protein concentrations utilized in these experiments, the SSB protein is in the tetrameric form. In vivo, however, SSB protein concentration controlled by the high-copy-number plasmids pLC10, pLC20, pLC30 and pLC40 in E. coli is not known. In each of these plasmids expression of the $s s b$ gene would appear to be controlled by its own promoter rather than by the lac promoter of the plasmid vector. pLC10 contains the $s s b$ gene in the opposite orientation to the lac promoter, while the $s s b$ genes on pLC30 and pLC40 are located more than a kilobase downstream of the lac promoter. While the $S$. hanedai $s s b$ gene on pLC20 could be expressed from the lac promoter of the vector, complementation of the E. coli ssb mutant PAM5779 also occurred in an $S$. hanedai plasmid clone containing the $s s b$ gene in the opposite orientation (data not shown). E. coli ribosome-binding and $\sigma^{70}$ promoter-like sequences are found upstream of all of the cloned $s s b$ genes.

pLC40, bearing the Shewanella PT99 ssb gene, and to a lesser extent plasmids pLC20 and pLC30, bearing the $S$. hanedai and Shewanella F1A ssb genes, exhibited weaker complementation abilities than the E. coli or Shewanella SC2A ssb plasmids. Complementation of either the E. coli $s s b$ deletion mutant or the $s s b$ point mutant by the PT99 $s s b$ was higher at $22^{\circ} \mathrm{C}$ than at $37^{\circ} \mathrm{C}$. It is tempting to speculate that the SSBs from the psychrotrophic or psychrophilic and barophilic shewanellas, S. hanedai, F1A and PT99, require conditions of low temperature or high pressure, or both, to function as efficiently as the SSBs from E. coli or from the mesophilic, moderate barophile Shewanella SC2A. However, we can not rule out the possibility that differences in the levels of the SSB proteins are also being reflected in the observed complementation patterns. An additional complicating factor is that the degree of Shewanella SSB- E. coli SSB heterotetramer formation is unknown.

The Shewanella SSB monomers range in size from $24.7 \mathrm{kDa}$ (S. hanedai) to $26 \cdot 3 \mathrm{kDa}$ (Shewanella SC2A), considerably larger than the E. coli SSB $(18 \cdot 8 \mathrm{kDa})$. This makes the Shewanella SSBs the largest bacterial SSBs 
Table 3. Percentage composition of eight amino acids as a function of total SSB protein, and conserved or variable protein sections

A, E. coli SSB; B, Shewanella SC2A SSB; C, S. hanedai SSB; D, Shewanella F1A SSB; E, Shewanella PT99 SSB.

\begin{tabular}{|c|c|c|c|c|c|c|c|c|c|c|c|c|c|c|c|}
\hline \multirow{2}{*}{$\begin{array}{l}\text { Amino } \\
\text { acid } \\
\text { residue }\end{array}$} & \multicolumn{5}{|c|}{ Total SSB protein } & \multicolumn{5}{|c|}{$\begin{array}{c}\text { Conserved portions of SSB } \\
\text { protein* }\end{array}$} & \multicolumn{5}{|c|}{$\begin{array}{c}\text { Central portion of SSB } \\
\text { protein } \dagger\end{array}$} \\
\hline & A & B & $\mathrm{C}$ & $\mathrm{D}$ & $\mathbf{E}$ & A & B & $\mathrm{C}$ & D & $\mathrm{E}$ & A & B & $\mathrm{C}$ & D & $\mathrm{E}$ \\
\hline $\operatorname{Arg}(\mathrm{R})$ & $5 \cdot 6$ & $4 \cdot 1$ & $3 \cdot 5$ & $3 \cdot 9$ & 3.5 & $7 \cdot 4$ & $5 \cdot 9$ & $5 \cdot 9$ & $5 \cdot 9$ & $5 \cdot 9$ & $1 \cdot 8$ & $2 \cdot 4$ & $0 \cdot 9$ & 1.8 & 0.9 \\
\hline $\operatorname{Asn}(\mathrm{N})$ & $4 \cdot 5$ & $7 \cdot 0$ & $4 \cdot 4$ & $3 \cdot 9$ & 3.5 & $4 \cdot 1$ & $5 \cdot 9$ & $5 \cdot 9$ & $6 \cdot 7$ & $5 \cdot 9$ & $5 \cdot 4$ & $8 \cdot 1$ & $2 \cdot 8$ & 0.9 & 0.9 \\
\hline$G \ln (Q)$ & $10 \cdot 2$ & $16 \cdot 1$ & $18 \cdot 6$ & $22 \cdot 9$ & $22 \cdot 0$ & $5 \cdot 7$ & $7 \cdot 6$ & $7 \cdot 6$ & $8 \cdot 4$ & $8 \cdot 5$ & $19 \cdot 6$ & $27 \cdot 5$ & $30 \cdot 8$ & $45 \cdot 0$ & $41 \cdot 3$ \\
\hline Gly $(G)$ & $16 \cdot 4$ & $10 \cdot 3$ & $9 \cdot 7$ & $8 \cdot 7$ & $8 \cdot 4$ & $11 \cdot 5$ & $7 \cdot 6$ & $7 \cdot 6$ & $7 \cdot 6$ & $7 \cdot 6$ & $25 \cdot 0$ & $17 \cdot 5$ & $12 \cdot 2$ & $12 \cdot 5$ & $11 \cdot 3$ \\
\hline Lys $(\mathrm{K})$ & $3 \cdot 4$ & $4 \cdot 1$ & $5 \cdot 3$ & $4 \cdot 8$ & $5 \cdot 7$ & 4.9 & $7 \cdot 6$ & $7 \cdot 6$ & $7 \cdot 6$ & $7 \cdot 6$ & $0 \cdot 0$ & $0 \cdot 0$ & $2 \cdot 8$ & $1 \cdot 3$ & $5 \cdot 0$ \\
\hline Pro $(\mathrm{P})$ & $6 \cdot 8$ & $8 \cdot 3$ & $10 \cdot 6$ & $8 \cdot 2$ & $6 \cdot 2$ & $2 \cdot 5$ & $2 \cdot 5$ & $3 \cdot 4$ & $2 \cdot 5$ & $2 \cdot 5$ & $16 \cdot 1$ & $10 \cdot 0$ & $18 \cdot 7$ & $12 \cdot 5$ & $6 \cdot 3$ \\
\hline $\operatorname{Ser}(S)$ & $5 \cdot 6$ & $4 \cdot 5$ & $4 \cdot 4$ & $5 \cdot 2$ & $6 \cdot 2$ & 4.9 & $5 \cdot 0$ & $5 \cdot 9$ & $5 \cdot 0$ & $5 \cdot 1$ & $8 \cdot 9$ & $6 \cdot 3$ & $2 \cdot 8$ & $6 \cdot 3$ & $10 \cdot 0$ \\
\hline $\operatorname{Tyr}(\mathrm{Y})$ & $2 \cdot 3$ & $4 \cdot 1$ & 4.9 & 3.9 & $3 \cdot 5$ & $3 \cdot 3$ & $4 \cdot 2$ & $4 \cdot 2$ & $4 \cdot 2$ & $4 \cdot 2$ & $0 \cdot 0$ & $4 \cdot 1$ & $5 \cdot 6$ & $3 \cdot 6$ & $2 \cdot 8$ \\
\hline
\end{tabular}

*Defined as residues 1-114 of the Shewanella SSBs (1-126 for the E. coli SSB) and the last six residues of the carboxy-terminal end of protein for all the SSBs.

†Defined as the central variable portion of the SSB proteins (as shown in Fig. 4).

identified to date (de Vries \& Wackernagel, 1993, 1994; Jarosik \& Hansen, 1994). An interesting pattern of migration is observed for the Shewanella SSBs on SDSPAGE gels (Fig. 5). As with the E. coli and Proteus mirabilis SSBs (de Vries \& Wackernagel, 1994; Lohman et al., 1986), the Shewanella SSBs all migrate more slowly than would be indicted by their calculated molecular masses. Even within the Shewanella SSB proteins there is no correlation between size and migration distance in SDS-PAGE. Curiously, the SSBs from the more extreme barophiles, Shewanella F1A and PT99, migrate the most slowly.

The division of the SSBs into highly conserved aminoterminal and carboxy-terminal portions separated by a variable central portion is in accordance with the presumed functions of these regions. The aminoterminal region, up to residue 115 , of the E. coli SSB is involved in both subunit interaction and the DNAbinding activity of the protein, and the conserved residues of the carboxy terminus are believed to interact with other proteins such as DNA polymerase II (Curth et al., 1996; also reviewed by Meyer \& Laine, 1990). It is not surprising therefore, that these regions are well conserved in the Shewanella SSBs. Interestingly, there are only three unconserved amino acid substitutions between the Shewanella SSBs in these regions. The replacement of polar residues with hydrophobic methionine residues at positions 48 and 106 in SSB from the mesophilic Shewanella SC2A could reflect adaptations to function at higher temperatures (Russell, 1990). Despite the variable nature of the central portion it is undoubtedly critical to SSB function. In vitro and in vivo analyses of $E$. coli SSBs bearing various deletions in the carboxy-terminal third of the protein indicate that this variable region of the protein is not required for DNA binding. However, a mutant E. coli SSB lacking the central variable region of the protein displays decreased affinity for ssDNA, suggesting that this region influences the DNA-binding capacity of the protein (Curth et al., 1996). Thus, the observed differences in the central portion of the Shewanella SSBs could be important to regulating DNA binding at different temperatures and pressures.

In all four Shewanella SSBs the variable central region is predominantly composed of alanine, glutamine, glycine and proline residues, but the distributon of these and other residues is not the same in all four Shewanella SSBs. For example, the central portion of the F1A and PT99 SSBs contains an extraordinarily high proportion of glutamine, $37 \%$ and $38 \%$ respectively, but the glutamine content of this portion of the SC2A SSB is only $24.4 \%$. Table 3 gives a breakdown of the percentage amino acid composition of eight amino acids, showing the greatest differences among the Shewanella SSBs presented as a function of the total protein, and conserved or variable protein sections.

Some of the differences in amino acid composition among the Shewanella SSBs correlate with differences previously observed in comparisons of homologous proteins adapted to different temperature regimes. Measurements of the hydrophilic character of the SSBs by the method of Hopp \& Woods (1981) indicate that the lower-temperature-adapted SSBs $(S$. hanedai, F1A and PT99) are dramatically more hydrophilic overall than their mesophilic counterparts (hydrophilicity values of $0 \cdot 113$ for SC2A SSB and $1 \cdot 2-1 \cdot 3$ for $S$. hanedai, F1A and PT99 SSBs). Proteins from mesophiles often possess fewer hydrophobic residues than their thermophilic counterparts (Zwickl et al., 1990; Zuber, 1988), where they are believed to play a major role in protein thermostability. It may also be noteworthy that the major cold-shock protein from E. coli, a protein which 
must function at the lower temperature limits for growth and survival of the organism, is also a highly hydrophilic protein (Goldstein et al., 1990). Comparison of the Shewanella SSBs also revealed decreased asparagine/ glutamine and arginine/lysine ratios with increased adaptation of the source organism to lower temperatures. This follows the trend observed among lactate dehydrogenases (Zuber, 1988). Asparagine predominates over glutamine in thermophilic lactate dehydrogenases for steric reasons. The arginine/lysine results are also consistent with the analysis of a variety of thermophilic and mesophilic proteins (reviewed by Mozhaev \& Martinek, 1984). Arginine is generally able to form one more intramolecular hydrogen bond than lysine (Mrabet et al., 1992), and thus may also be important in protein thermostability.

Perhaps the most intriguing amino acid substitutions observed were those identified among the Shewanella SSBs which correlate with pressure adaptation of the source organism. This is because amino acid substitutions important for protein structure/function at biologically relevant elevated pressures have yet to be identified. The striking hydrophilicity of the deep-sea bacterial SSBs is significant in this context because hydrophobic interactions have been implicated in the high-pressure stabilization of proteins from thermophiles (Hei \& Clark, 1994). Curiously, among the polar residues there is a barophilic bias towards serine in place of tyrosine. Another striking difference between the Shewanella SSBs is in the combined total of the helixdestabilizing glycine residues, and the helix-breaking proline residues. There is a progressive decrease in the number of these residues extending from $S$. hanedai, which was isolated from the shallowest waters, to Shewanella PT99, which was isolated from the deepest marine environment and is an obligately barophilic isolate. This trend is even more obvious when only the central portion of the SSBs is examined. A loss of prolines and glycines argues for a decrease in flexibility. Globular proteins with low flexibility also exhibit low compressibility (Gross \& Jaenicke, 1994). Interestingly, proline to glycine substitutions in staphylococcal nuclease which decrease chain flexibility increase the stability of the protein at high pressure (Royer et al., 1993). Therefore, increased structural homogeneity could be favoured by the high-pressure environments of the deep sea.

In order to determine SSB residues critical to psychroand baro-adaptation it will be necessary to perform comparative studies of the effects of low temperature and high pressure on the quaternary structure and the DNA-binding capacity of purified Shewanella SSBs and mutant proteins obtained by site-directed mutagenesis. Some of these experiments are now in progress.

\section{ACKNOWLEDGEMENTS}

This work was supported by an augmentation award for science and engineering research training (ONR N00014-94-10888) from the office of Naval Research. We are indebted to the following scientists for plasmids and strains used in this study: Steve Worland, Ronald Porter, Wilfried Wackernagel, Edward DeLong, Holger Jannasch and Aristides Yayanos.

\section{REFERENCES}

Altschul, S. F., Gish, W., Miller, W., Myers, E. W. \& Lipman, D. J. (1990). Basic local alignment search tool. J Mol Biol 215, 403-410.

Brandsma, J. A., Bosch, D., de Ruyter, M. \& van de Putte, P. (1985). Analysis of the regulatory region of the $s s b$ gene of Escherichia coli. Nucleic Acids Res 13, 5095-5109.

Bujalowski, W. \& Lohman, T. M. (1991). Monomer-tetramer equilibrium of the Escherichia coli ssb-1 mutant single strand binding protein. J Biol Chem 266, 1616-1626.

Curth, U., Genschel, J., Urbanke, C., Greipel, J. (1996). In vitro and in vivo function of the C-terminus of Escherichia coli singlestranded DNA binding protein. Nucleic Acids Res 24, 2706-2711.

Davis, R. W., Botstein, D. \& Roth, J. R. (1980). Advanced Bacterial Genetics. Cold Spring Harbor, NY: Cold Spring Harbor Laboratory.

DeLong, E. F. \& Yayanos, A. A. (1986). Biochemical function and ecological significance of novel bacterial lipids in deep-sea procaryotes. Appl Environ Microbiol 51, 730-737.

Devereux, J., Haeberli, P. \& Smithies, O. (1984). A comprehensive set of sequence analysis programs for the VAX. Nucleic Acids Res 12, 387-395.

Feng, D.-F. \& Doolittle, R. F. (1990). Progressive alignment and phylogenetic tree construction of protein sequences. Methods Enzymol 183, 375-387.

Foguel, D. \& Silva, J. (1994). Cold denaturation of a repressoroperator complex: the role of entropy in protein-DNA recognition. Proc Natl Acad Sci USA 91, 8244-8247.

Goldstein, J., Pollitt, N. S. \& Inouye, M. (1990). Major cold shock protein of Escherichia coli. Proc Natl Acad Sci USA 87, 283-287.

Gross, M. \& Jaenicke, R. (1994). Proteins under pressure - the influence of high hydrostatic pressure on structure, function and assembly of protein complexes. Eur J Biochem 221, 617-630.

Hammar, M., Arnqvist, A., Bian, Z., Olsen, A. \& Normark, S. (1995). Expression of two csg operons is required for production of fibronectin- and Congo red-binding curli polymers in Escherichia coli K-12. Mol Microbiol 18, 661-670.

Hanahan, D. (1983). Studies on transformation of Escherichia coli with plasmids. J Mol Biol 166, 557-580.

Hei, D. J. \& Clark, D. S. (1994). Pressure stabilization of proteins from extreme thermophiles. Appl Environ Microbiol 60, 932-939.

Hoffman, L. M. \& Jendrisak, J. (1990). Heat-labile phosphatase simplifies the preparation of dephosphorylated vector DNA. Gene 88, 97-99.

Hopp, T. P. \& Woods, K. R. (1981). Prediction of protein antigenic determinants from amino acid sequences. Proc Natl Acad Sci USA 78, 3824-3828.

Hostomski, Z., Appelt, K. \& Ogden, R. C. (1989). High level expression of self-processed HIV-I protease in E. coli using a synthetic gene. Biochem Biophys Res Commun 161, 1056-1063.

Jaenicke, R. (1991). Protein stability and molecular adaptation to extreme conditions. Eur J Biochem 202, 715-728.

Jannasch, H. W. \& Wirsen, C. O. (1984). Variability of pressure adaptation in deep-sea bacteria. Arch Microbiol 139, 281-288.

Jarosik, G. P. \& Hansen, E. J. (1994). Cloning and sequencing of the Haemophilus influenzae ssb gene encoding single-strand DNA-binding protein. Gene 146, 101-103. 
Jensen, M. J., Tebo, B. M., Baumann, P., Mandel, M. \& Nealson, K. H. (1980). Characterization of Alteromonas hanedai (sp. nov.), a nonfermentative luminous species of marine origin. Curr Microbiol 3, 311-315.

Johnson, B. F. (1977). Genetic mapping of the lexC-113 mutation. Mol Gen Genet 157, 91-97.

Jones, P. G., Krah, R., Tafuri, S. R. \& Wolffe, A. P. (1992). DNA gyrase, CS7.4, and the cold shock response in Escherichia coli. J Bacteriol 174, 5798-5802.

Laemmli, U. K. (1970). Cleavage of structural proteins during the assembly of the head of bacteriophage T4. Nature 227, 680-685.

Lohman, T. M., Green, M. J. \& Beyer, R. S. (1986). Large-scale overproduction and rapid purification of the Escherichia coli ssb gene product. Expression of the $s s b$ gene under lambda $\mathrm{P}_{\mathrm{L}}$ control. Biochemistry 25, 21-25.

Ludlow, J. M. \& Clark, D. S. (1991). Engineering considerations for the application of extremophiles in biotechnology. Crit Rev Biotechnol 10, 321-345.

Macgregor, R. B. (1992). Footprinting of EcoRI endonuclease at high pressure. Biochim Biophys Acta 1129, 303-308.

Merrill, B. M., Williams, K. R., Chase, J. W. \& Konigsberg, W. H. (1984). Photochemical cross-linking of the Escherichia coli singlestranded DNA-binding protein to oligo deoxynucleotides. Identification of phenylalanine 60 as the site of cross-linking. J Biol Chem 259, 10850-10856.

Meyer, R. S. \& Laine, P. S. (1990). The single-stranded DNAbinding protein of Escherichia coli. Microbiol Rev 54, 342-380.

Mozhaev, V. V. \& Martinek, K. (1984). Structure-stability relationships in proteins: new approaches to stabilizing enzymes. Enzyme Microb Technol 6, 50-59.

Mrabet, N. T., Van den Broeck, A., Van den Brande, I. \& 13 other authors (1992). Arginine residues as stabilizing elements in proteins. Biochemistry 31, 2239-2253.

Norrander, J., Kampe, T. \& Messing, J. (1983). Construction of improved M13 vectors using oligonucleotide-directed mutagenesis. Gene 26, 101-106.

Porter, R. D. \& Black, S. (1991). The single-stranded-DNA-binding protein encoded by the Escherichia coli $\mathrm{F}$ factor can complement a deletion of the chromosomal ssb gene. J Bacteriol 173, 2720-2723.

Porter, R. D., Black, S., Pannuri, S. \& Carlson, S. (1990). Use of the Escherichia coli ssb gene to prevent bioreactor takeover by plasmidless cells. Bio/Technology 8, 47-51.

Rentier-Delrue, F., Mande, S. C., Moyens, S., Terpstra, P., Mainfroid, V., Goraj, K., Lion, M., Hol, W. G. J. \& Martial, J. A. (1993). Cloning and overexpression of the triosephosphate isomerase genes from psychrophilic and thermophilic bacteria. $J$ Mol Biol 229, 85-93.

Robinson, C. R. \& Sligar, S. G. (1995). Hydrostatic and osmotic pressure as tools to study macromolecular recognition. Methods Enzymol 259, 395-422.

Royer, C. A. (1995). Application of pressure to biochemical equilibria: the other thermodynamic variable. Methods Enzymol 259, 357-377.

Royer, C. A., Chakerian, A. E. \& Mathews, K. S. (1990). Macromolecular binding equilibria in the lac repressor system: studies using high pressure fluorescence spectroscopy. Biochem 29, 4959-4966.

Royer, C. A., Hinck, A. P., Loh, S. N., Prehoda, K. E., Peng, X., Jonas, J. \& Markley, J. L. (1993). Effects of amino acid substitutions on the pressure denaturation of staphylococcal nuclease as monitored by fluorescence and nuclear magnetic resonance spectroscopy. Biochemistry 32, 5222-5232.

Russell, N. J. (1990). Cold adaptation of microorganisms. Philos Trans $R$ Soc Lond B 326, 595-611.

Saiki, R. K., Gelfand, D. H., Stoffel, S., Scharf, S. J., Higuchi, R., Horn, G. T., Mullis, K. B. \& Ehrlich, H. A. (1988). Primer directed enzymatic amplification of DNA with a thermostable DNA polymerase. Science 239, 487-491.

Sambrook, J., Fritsch, E. F. \& Maniatis, T. (1989). Molecular Cloning: a Laboratory Manual. Cold Spring Harbor, NY: Cold Spring Harbor Laboratory.

Silhavy, T., Berman, M. L. \& Enquist, L. W. (1984). Experiments with Gene Fusions. Cold Spring Harbor, NY: Cold Spring Harbor Laboratory.

Silva, J. L. \& Weber, G. (1993). Pressure stability of proteins. Annu Rev Phys Chem 44, 89-113.

Smith, D. W. (1988). A complete yet flexible system for DNA/ protein sequence analysis using VAX/VMS computers. Comput Appl Biosci 4, 212-220.

Somero, G. N. (1992a). Biochemical ecology of deep-sea animals. Experientia 48, 537-543.

Somero, G. N. (1992b). Adaptations to high hydrostatic pressure. Annu Rev Pbysiol 54, 557-577.

Southern, E. M. (1975). Detection of specific sequences among DNA fragments separated by gel electrophoresis. J Mol Biol 98, 503-517.

Staden, R. (1988). Methods to define and locate patterns in sequences. Comput Appl Biosci 4, 53-60.

Swofford, D. L. (1991). PAUP: phylogenetic analysis using parsimony. Champaign, IL: Illinois Natural History Survey.

Tabor, S. \& Richardson, C. C. (1985). A bacteriophage T7 RNA polymerase/promoter system for the exclusive expression of specific genes. Proc Natl Acad Sci USA 82, 1074-1078.

Tobal, G. M. (1993). Purification and characterization of a malate debydrogenase from the marine bacterium Shewanella SC2A. Masters thesis, University of California, San Diego.

de Vries, J. \& Wackernagel, W. (1993). Cloning and sequencing of the Serratia marcescens gene encoding a single-stranded DNAbinding protein (SSB) and its promoter region. Gene 127, 39-45.

de Vries, J. \& Wackernagel, W. (1994). Cloning and sequencing of the Proteus mirabilis gene for a single-stranded DNA-binding protein (SSB) and complementation of Escherichia coli ssb point and deletion mutations. Microbiology 140, 889-895.

de Vries, J., Genschel, J., Urbanke, C., Thole, H. \& Wackernagel, W. (1994). The single-stranded-DNA-binding proteins (SSB) of Proteus mirabilis and Serratia marcescens. Eur J Biochem 224, 613-622.

Walker, G. C. (1984). Mutagenesis and inducible responses to deoxyribonucleic acid damage in Escherichia coli. Microbiol Rev 48, 60-93.

Weber, G. (1992). Protein Interactions. New York: Chapman \& Hall.

Welch, T. J., Farewell, A., Neidhardt, F. C. \& Bartlett, D. H. (1993). Stress response in Escherichia coli induced by elevated hydrostatic pressure. J Bacteriol 175, 7170-7177.

Yayanos, A. A. (1995). Microbiology to 10,500 meters in the deep sea. Annu Rev Microbiol 49, 777-805.

Yayanos, A. A., Dietz, A. S. \& Van Boxtel, R. (1982). Dependence of reproduction rate on pressure as a hallmark of deep-sea bacteria. Appl Environ Microbiol 44, 1356-1361. 
Zuber, H. (1988). Temperature adaptation of lactate dehydrogenase. Structural, functional and genetic aspects. Biophys Chem 29, 171-179.

Zwickl, P., Fabry, S., Bogedain, C., Haas, A. \& Hensel, R. (1990). Glyceraldehyde-3-phosphate dehydrogenase from the hyperthermophilic archaebacterium Pyrococcus woesi: characteri- zation of the enzyme, cloning and sequencing of the gene, and expression in Escherichia coli. J Bacteriol 172, 4329-4338.

Received 9 August 1996; revised 24 October 1996; accepted 6 November 1996. 